\title{
Pauline Johnson's Sapphic Wampum
}

\section{LiNDA REVIE}

Linda Revie teaches in the School of English and Theatre Studies at the University of Guelph. Her doctoral thesis on Niagara Falls, The Niagara Companion: Explorers, Artists and Writers at the Falls from Discovery Through the Twentieth Century, will be published by Wilfrid Laurier University Press in 2003. Her current research, funded through the Hannah Institute for the History of Medicine, investigates an early-twentieth-century Canadian philanthropist involved in birth control production and eugenical sterilizations.

We dance round in a ring and suppose, But the Secret sits in the middle and knows.

- Robert Frost (153)

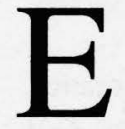

Pauline Johnson (1861-1913), Canada's famous poet born of a Mohawk father and a Quaker mother, has been called - "The Boadicea" of New England and "The Sappho" of the New World ${ }^{1}$ because she donned costumes of buckskin, then Victorian lace, and delivered to audiences in Canada, the U.S.A., and Great Britain strange and pagan tales of Indian glory followed by lyrics of love lost and regained. Johnson's first biographer Annie Foster has also compared her to British poet Elizabeth Barrett Browning. Although Foster claims Johnson and Browning share a

${ }^{1}$ The Pall Mall Gazette was the first to dub Pauline Johnson an "Indian Boadicea" in 1906 (qtd. in McRaye 102); in 1913 Thompson Seton indirectly compared the poet to Boadicea (Johnson, Shagganappi, Introduction, n.p.) and in 1931 biographer Annie Foster wrote that Johnson "resembles Sappho more than any other poet" (97). Boadicea, queen of the Celtic Iceni tribe in the east of Britain, is known to have led a revolt against the Romans, but was finally defeated in A.D. 61 and took her own life. Sappho, a Greek lyric poet born in Lesbos about the middle of the 7 th century B.C., wrote tender, impassioned love poems, mostly to women.

torquere: Journal of the Canadian Lesbian and Gay Studies Association I Revue de la Société canadienne des études lesbiennes et gaies Vol. 4-5 (2002-2003) @ CLGSA / SCELG 
focus on natural imagery, she implies that the Mohawk Princess's verse is more "primitive" and "racial" (97-98). These associations with Boadicea (the "savage"-warrior) and with Sappho and Browning (the gentlewomen-love poets) signal the competing personae that Pauline Johnson brings to her work.

As if to confirm her double nature, early on in her career Johnson began using an inherited nom de plume - Tekahionwake - an Indian word she translated as "two wampums" (Duncan n.p). Wampum, a bead manufactured from shells, possessed spiritual power: "strung or woven into collars and belts, it provided mnemonic devices that recorded transactions such as alliances" (Dickason 78). Johnson's explication of the Indian word - "As wampum to the Redman, so to the Poet are his songs" (White Wampum, Dedication) - further connects these notions of wampum as narrative, memory, confederacy/espousal, and adds another dimension of performance too, through the word "songs." Further, Johnson's publicity stills play up aspects of her persona as performance poet and exotic Indian (see the two photographs on the cover of Johnston's Buckskin \& Broadcloth), and the recent study of her life and work by Veronica Strong-Boag and Carole Gerson thoroughly examines this warrior / gentlewoman duality to argue that Johnson was "double-voiced" and "double-garbed" (69-70). Yet critics have not analyzed the ways in which the Mohawk Princess's lyrics, recitals, and social appearances play upon the Sappho role, or how the life may be considered Sapphic.

While there are many missing pieces to the Johnson biography, there is much speculation where gaps appear in her writing and life. This essay rereads Johnson and intervenes in biographical criticism by arguing that assumptions of her heterosexuality have prevented previous critics from understanding the extent to which her life story encompasses a lifelong love for women. In performing this critique, I employ the methodology of the Lesbian History Group (LHG) that challenges biographers to think of all women as in some sense lesbian, "within a lesbian continuum" (13). According to the LHG, reclaiming lesbians in history is imperative because it casts light not only on the lives of people in a minority but also on the values and beliefs of those who wish to keep lesbians a minority. Every social group needs access to its own history, the LHG argues, and knowledge of the past provides cultural roots and a heritage from 
which to learn. Consequently, it is important to stop rewriting lesbian history into more "acceptable scripts" that expunge lesbianism and construct lesbians as heterosexual (2). In the following, I examine the evidence that biographers have collected about Pauline Johnson's love life and I trace the textual history of her hidden sexuality.

Biographer Annie Foster may have evoked Sappho as the sole example of a classical woman poet who could legitimate women as serious poets, yet one of the admired features of Sappho's work is that often both subject and object of shared passion are women. The identification of, and with, Sappho as a lesbian figure - a centuriesold association - was made popular during the Victorian era by British author Algernon Charles Swinburne (1837-1909). As Swinburne's Dedication to Poems and Ballads: First Series shows, Sappho, the "supreme head of song," is his presiding muse. Published in 1866, this collection of lyrics glorified bisexuality and lesbianism, making them into gestures of social and cultural rebellion. According to Swinburne biographer Rikky Rooksby, the book scandalized Victorian critical moral opinion and was withdrawn from circulation by its publisher, Moxon (Rooksby 691). Nonetheless, the cultural impact of Poems and Ballads was "immense ... it made [Swinburne] an international figurehead for sexual, religious and political radicalism" (135). In a recent biography of Pauline Johnson, Charlotte Gray claims that Johnson "declared herself a devotee" of Swinburne, and that she always traveled with a copy of his verse (79, 302). Additionally, when Johnson's first book of poetry The White Wampum (1895) was reviewed in the Manchester Guardian, an anonymous critic praised the "Swinburnian style" of certain pieces, especially "The Idlers" and "Re-Voyage" (qtd. in StrongBoag/Gerson 145). Of the two, "Re-Voyage" borrows part of its form from Swinburne's "Sapphics," which is, in turn, modeled on the classical Sapphic stanza's celebrated hendecasyllable line.

An awareness of the sapphic nature of Johnson's The White Wampum might have been prompted, as well, by her choice of publisher - John Lane. Many of the books published by Lane during the 1890 s were by 'New Women' writers who focused on the woman as sexual object. Included in this list were novels that profiled masculine, strong-minded female characters who sometimes crossdressed, such as George Egerton's Keynotes (1893), Sarah Grand's The Heavenly Twins (1893), Iota's The Yellow Aster (1893), and 
Emma Brooke's The Superfluous Woman (1894). These so-called "yellow lady writers" were criticized in Blackwood's Magazine as being "morbid," "disgusting," even "degenerate" (Stutfield 833-34). The press also received negative attention because Oscar Wilde, the "father of the whole flock," was one of Lane's authors, Aubrey Beardsley designed many of Lane's covers, and Richard Le Gallienne was one of Lane's readers (840). When Pauline Johnson visited England in 1894 (the year Wilde was sentenced), she met Beardsley, and Le Gallienne read her manuscript and helped select the poems to be included in The White Wampum (McRaye 42, 51).

Swinburne's erotic verse and Lane's 'New Women' publications aside, the nineteenth-century literary practice of sapphism was mostly a coded affair. It is known that upper-class British 'spinster' Anne Lister invented a cipher to chronicle her passionate love affairs with other women between 1817-24. Lister's other codes included a nickname - 'Fred' or 'Freddy' — and a masculine appearance and manner (Lister 105, 64). Queer theorist Paula Bennett argues that other famous American writers such as Emily Dickinson, Lydia Sigourney, Amy Lowell, and Harriet Spofford used a semiprivate code of sexual 'flower' imagery to convey ideas of homoerotic lust and desire (250). 'Canoes' may have been another means by which nineteenth-century women expressed passion and same-sex desire. Louisa May Alcott's 1868 article "Happy Women" argues for independent spinsters being free spirits "paddling their own canoes" (n.p). And the Canadian poet Isabella Valancy Crawford's "Lily Bed" and "Malcolm's Katie" (1884) involved suggestive allusions to female erotic arousal within the context of Indian legends that included canoes.

On the other hand, the social and cultural practice of lesbianism during the eighteenth and nineteenth centuries was defined through dress, profession, and marital status (see Donoghue; Everard).The assumption of male clothes was a means through which women dramatized their selves and desires. The actress Charlotte Charke (1713-1760) who had an extensive stage career particularly in male roles, dressed in men's clothes off the stage, admitted that women were attracted to her, and lived with another actress (Morgan 19). The French painter Rosa Bonheur (1822-99) who spent her adult life wearing male attire and living with Nathalie Micas, was amused by people who wondered whether she was a spinster or bachelor. 


\section{2 / Revie}

Other cross-dressing nineteenth-century bohemian women include George Sand (1804-1876), who was for a brief period madly in love with the actress Marie Dorval, and the upper-class "Ladies of Llangollen" - Eleanor Butler (1739-1829) and Sarah Ponsonby (1755-1831) - who ran away from threats of marriage and the convent to live with each other in remote north Wales. Lady Eleanor was described as the more 'mannish.' And the enormously popular British author Adelaide Procter (1825-1864), who loved another woman, wrote a poem that openly expressed her passion ("To M.M.H."), then she explicitly dedicated her Legends and Lyrics (1858) to that same lover, the theatrical cross-dresser Matilda M. Hays (Faderman 223-25; Gregory 24-25; Vicinus 432, 440-41).

In all probability, Pauline Johnson knew about cross-dressing and lesbian women, since among the collection of her books bequeathed to friends was The Complete Works of Adelaide Procter (1905). And evidence shows that similar preoccupations with dress, lifestyle, relationships, and interests shaped Pauline Johnson's life. Eva Johnson describes how her sister smoked Cuban cigars and dressed in her brother's clothes (qtd. in Johnston 58-59). Further, Foster's 1931 biography states that Pauline Johnson had a few male nicknames: "Paul" was her family moniker and the pet name used by her teenaged friend Jean Morton (29), and later in life the poet abbreviated her own surname to call herself "John" or "Johnlums." Even more fascinating, an acquaintance in Johnson's Vancouver group seems to have tapped into a coded lesbian tradition when she chose to go by "Tommy." "Tommy" is a slang word for a woman who has sex with other women: its usage dates back to 1773, though this connotation has never been recorded in The Oxford English Dictionary (Donoghue 5). Other words used by Johnson that stand for a complex of concerns include "fellowship" and "extreme womanhood" (from a letter to a former Brantford neighbor, qtd. in Johnston 203). To locate the codes by which she named the love that so famously could not speak its name is to see how Pauline Johnson both produced and disguised her homosexuality.

\section{The Love Life Reconstructed}

Over the last seventy years, biographers have thoroughly examined the scanty supply of evidence about Pauline Johnson's love relationships. Partially, Johnson's sister Eva - who was stamped 
with a more conventional design - is to blame for the dearth of information. In order to 'protect' the poet's reputation after death, Eva Johnson burned the personal letters and diaries, and ordered Johnson's business partner J. Walter McRaye to do the same. ${ }^{2}$ The evidence shows that Johnson resisted marriage, despite at least eight proposals from men (Johnston 70). We know that as a teenager, she embroidered leather tobacco pouches for five young suitors who were all competing for her attention (Foster 31 ). She chose none. She had professional relationships with men, first with the boyish British entertainer Owen Alexander Smily, who, as one biographer speculates, was probably homosexual (Keller 68), ${ }^{3}$ and then with McRaye (nicknamed "The Dink" by Johnson) who ended up marrying her childhood friend Lucy Webling. The poet was engaged to Charles Drayton, whom she met in the summer of 1877 (Martin D3), but they did not marry. While the facts about her life before and after this severed relationship are confused, the date of her engagement to Drayton (25 Jan. 1898) came after Johnson's final breakup with Smily (Dec. 1897) and just days before her mother died (Feb. 1898). It is known that immediately after her mother's funeral Johnson went to Ottawa and did not return to the entertainment circuit with a one-woman variety show until the Fall of 1898. Then sometime between Christmas 1899 and 9 January 1900 her engagement to Drayton dissolved (Johnston 150-51). A letter to Regina-based journalist Kate Simpson-Hayes on 3 February 1899 - during the confused time when the poet was supposed to be engaged - may offer clues. In the note Johnson rejects her friend's offer of accommodation but uses a very sexual language to do so:

"Now you know you are alluring, your invitation is like sin, tempting, insinuating, insistent, and I, in virtuous chase after dollars, stoically turn my back on it, prayerfully resist

2 Three decades after Pauline Johnson's death, McRaye was still trying to 'save' the poet's reputation. In 1947, would-be biographer Dr. Gilbert Monture attempted to glean some undisclosed facts about Johnson but McRaye, who declined to gossip, replied: "'I know what you are after, Doctor, but you will never hear any word pass my lips that would in anyway affect the reputation of our dear and gracious Pauline"” (Van Steen 42).

3 The Smily-Johnson team lasted a total of five years, from November 1892 until April 1894, when Johnson left Smily to go to England, and then from July 1894 until December 1897. 
it and with bated breath, locked teeth and averted eyes dash past, resisting the fascination of it and thus gaining a crown of glory - composed of many bank notes and jingling coin of the realm." (Qtd. in Strong-Boag/Gerson 96)

This note, and a couple of extraordinary short confessional poems about parting from a lover (analyzed below) suggest at least two reasons why Pauline Johnson refused to occupy the wifely niche that society had prepared for her: she was interested in women and in making money. For the most part, biographers cite the difference in age (11 years), her "immoral" profession, or her mixed race as reasons for the failed engagement (Gray 247; Keller 133-35; StrongBoag/Gerson 68,104$)$. In any case, her chosen path of poet / actress was an unconventional career that appears to have caused "the first rift" between Johnson and her family (Keller 62).

Biographer Betty Keller also speculates that Johnson had an illicit affair during the summer of 1900 with her manager Charles Wurz, a married man (160). But during the time she may have known Wurz, Johnson was in Halifax suffering from rheumatic fever brought on by a streptococcus infection (Keller 154-55). There is no evidence to prove that Johnson slept with Wurz, or with any other man. To add to the mystery, there is the poet's dying request to be cremated with a small gold shield-shaped locket containing the photograph of "a young boy" ("Were Her Wishes Observed?" 13). Although no one knows the identity of that person - perhaps the picture in the locket was of a "foster" child, ${ }^{4}$ or of the poet herself being "boyish," or of a female friend playing the tom? - Keller suggests he was a male lover (267-68) and Gray identifies him as Michael Mackenzie or Archie Kains ${ }^{5}(99,132)$.

Why this need to pair her up in a heterosexual union? Johnson herself has written in letters addressed to friends Jean Morton and

${ }^{4}$ McRaye tells a story about Johnson assisting a woman and her three small children on a train. One of the babies was a foster child and, over the years, the poet kept track of that little girl - whom the parents named Pauline - and sent her a locket, clothes, and money (Keller 192-93).

5 Gray admits that the friendship between Johnson and Michael Mackenzie "never blossomed into anything romantic" but she still considers Mackenzie responsible for leaving "a permanent scar on the poet's heart" $(100,102)$. Similarly, Gray writes that Johnson's relationship with Archie Kains was "not a successful romance, but rather a comfortable companionship" (135). 
Floretta Maracle that her relationships with women were the center of her life (Strong-Boag/Gerson 68; 25 $\ln 27$ ). Pauline Johnson adored women: beginning with Morton of Brantford, her "bonny girl" of the 1870s, and ending with Eileen Maguire of Vancouver, known inheritor of two of the poet's rings and referred to as "my beloved" in her will of 1913. As the LHG argues, a woman who "puts on record that she lived with or loved another woman, can be assigned a lesbian identity with rather more validity than many of the heterosexual ones that biographers have scattered about" (15). Over her lifetime, she may have had many alliances of the heart. Pictures of Johnson from her early and later years frequently show her flanked by a woman identified as Raby Wye (see the two photographs accompanying this essay). Like Sappho's circle of girls, who came not only from Lesbos but from all parts of Greece, those in Johnson's group trekked across the nation to be with her. Miss Kate McKeand, a Brantford friend, was frequently a guest at Dr. Lighthall's residence in Montreal when Johnson was there. ${ }^{6}$ The two Webling sisters, Lucy and Rosalind, both moved from Brantford to Vancouver to be closer to their friend. ${ }^{7}$ Bertha Jean Thompson, an acquaintance from a camping holiday in Ontario, also relocated to Vancouver and became one of the poet's 'protégées'; and Brantford-born Miss Nellie Van Fleet traveled from the Fraser River farm she shared with Miss Ethel Hanwell to bring an ill Pauline Johnson a pint of freshly picked strawberries (Foster 134). There was the so-called Friendship Group, a support-team for the dying poet, including Miss Isabel "Alexandra" McLean and her friend Miss A. M. Ross, who took a room in the same house in order to care for the poet (Foster 136). Then there were all the friends who were bequeathed personal items such as a toothbrush handle (Isabel Ecclestone MacKay), a comb (Nellie McClung), silver waist buttons (Bertha Browning), and two rings (Eileen Maguire) ("Were Her Wishes Observed?" 14). That Johnson bequeathed personal items to MacKay and McClung is not necessarily indicative of anything more

${ }^{6}$ Not much is known about McKeand, except that she dressed a doll in imitation of the poet for Lighthall's daughter (Foster 133).

${ }^{7}$ The Webling girls emigrated from England to Brantford in the 1890s. Lucy Webling formed part of Pauline Johnson's canoeing group that went to Camp KnockAbout in Muskoka. At one of these camp-outs Johnson honored her friend with a poem. Lucy Webling also went on tour with Johnson and her circuit partner McRaye. In 1909 Lucy Webling and McRaye married (Foster 67). 
than her regard for them as sister authors. Other offerings to McRaye, Dr. T. R. B. Nelles, her brother Allen Johnson, Bert Cope, and Frank Cope suggest her regard for them as friends. But the fact that she bequeathed a pair of rings to her "beloved" Eileen Maguire implies a particular intimacy. In reappraising Pauline Johnson's life and loves we need to address her most important relationships with women.

Previous biographers of Pauline Johnson practice a form of erasure by arguing for the poet's unions with her female friends as 'conventional' homosocial relations. Strong-Boag and Gerson suggest that the poet's passionate feelings for her girlfriends were 'normal' during the Victorian age, when "women commonly turned to one another for affection and support; the advent of husbands and children need not break those close ties" (64). Keller describes Johnson's early love poetry as "typical of the highly sentimental verses that girls of this period presented to one another" (36). Gray speaks of one of these lyrics as "a throbbing testament to friendship" (78). Basically, the biographers assume that Johnson and her female

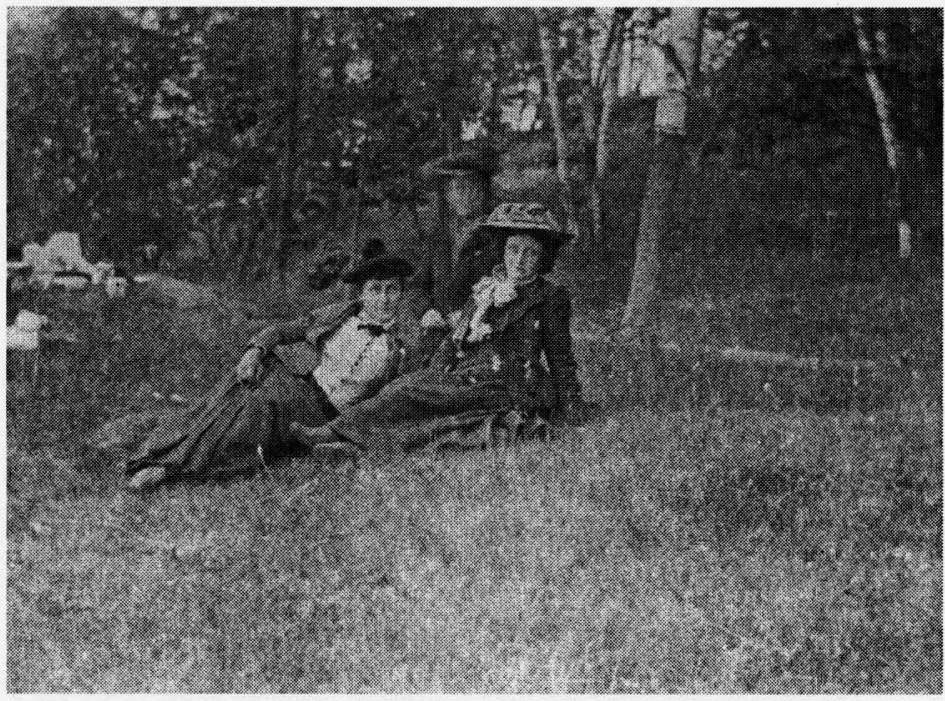

This undated photograph of Pauline Johnson (reclining, left) relaxing with Raby Wye (reclining, right) and an unidentified person had been glued to the inside cover of her "canoeing" scrapbook. (The William Ready Division of Archives \& Research Collections, McMaster University Library, Hamilton, Canada.) 
friends were all heterosexual and that any passions between them were platonic. While it was common for girls of this era to be emotionally and even physically close, Johnson's relationships with her female friends are more than just 'schoolgirl crushes' as they continued long after she had left school. Because she forged intense relationships with women throughout her adult life, and because she did not turn her affections toward a husband or children, it seems that a radical change of sexuality did not occur after her formative years, but rather the opposite happened: her desire remained constant.

While the poet's commitment to women seems to have been consistent, the Mohawk Princess's understanding of how to present, and perform, her femininity went through a radical change early on in her career. She began to manipulate her social guise in 1892 when she fashioned an "Indian" dress. A letter from Johnson to her editor W. D. Lighthall makes it clear how the design of the garment is a construction of both race and gender:

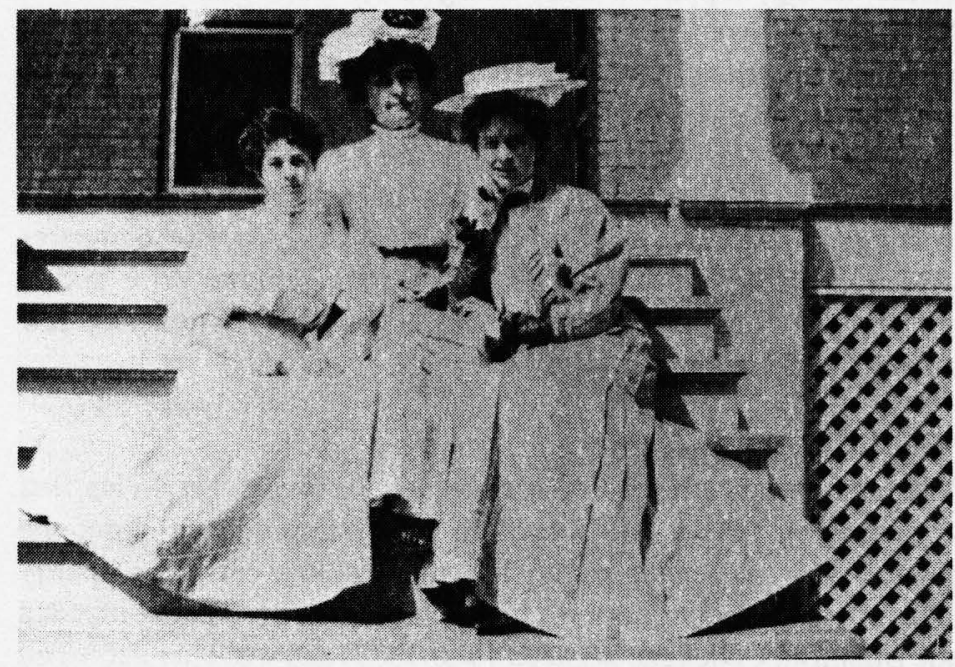

This photograph of Pauline Johnson (seated, center) flanked by Mrs. Carter, J. Walter McRaye's cousin (left) and Raby Wye (right) was taken during a visit to Boulder, Colorado, in 1907. Johnson and McRaye were performing in the area, with the Chautauqua entertainment circuit. (The William Ready Division of Archives \& Research Collections, McMaster University Library, Hamilton, Canada.) 
This season I am going to make a feature of costuming for recitals - always an interesting topic with ladies, but I am beset with difficulties on all hands. For my Indian poems I am trying to get an Indian dress to recite in, and it is the most difficult thing in the world. Now I know you know what is feminine, so you can tell me if the 'Indian stores' in Montreal are real Indian stores, or is their stuff manufactured? ... I want one that is made up of feminine work. (Qtd. in Strong-Boag/Gerson 110)

The asymmetrical buckskin costume she wears in her publicity still (see the cover of Johnston's Buckskin \& Broadcloth) is one-sleeved, fringed and embellished with wampum beads, a tomahawk, and a bear-claw necklace. But what is most significant about the garb is the self-consciousness behind its construction, especially Johnson's emphasis on how she needs to look "feminine." The sexual dimension of her life could have influenced this choice. Under the prevalent psychiatric and medical discourses in the West during the 1880s and 1890s, especially the writings of German sexologist Richard von Krafft-Ebing, sapphism and 'savageness' were both considered "degenerate," even "perverse" (see Terry 46), yet the appearance of civility, high social standing, and 'normalcy' that came with looking ladylike might circumvent these prejudices against Nativeness and lesbianism. In reassessing Pauline Johnson, we need to draw out other self-conscious constructions to see how her sexuality influenced her writings. I turn now to a formal poetical analysis that compares selections of her work to nineteenth-century sapphic verse and in the process, I question past biographical assertions to motivate new ways of reading Pauline Johnson.

\section{The Poems Reconsidered}

Pauline Johnson's friend Jean Morton was the inspiration for her first love poems. "My Little Jean," an eight-stanza verse about the predominant nineteenth-century idea that true love embodies a purity of spirit, appeared in Morton's high school album (Johnson attended the Brantford Collegiate between 1876-1877) and was later published in Gems of Poetry (1883). In the following excerpt, stylistic effects in stanza six include a variation of consonance ("life-love-love") and a dash, calling attention to the words "love" and "untrue," thereby stressing the poem's message that if the lovers sublimate and purify 
their affections, their passion will remain free of physical 'manly' aspects, and their feelings for each other will stay 'true.'

Your friendship has sufficed, and held its own

Unsullied still,

What manly voice upon my heart has grown,

What stronger hand can soothe like yours alone

My headstrong will?

Life offers me no love but love for you,

My woman's thought

Was never given to test a faith untrue-

Nor drink of passion's spirits drugged with rue,

Too dearly bought. ${ }^{8}$

The speaker goes on to confess in the opening of the next stanza, "They say sometimes my wayward heart must rise, / To love so strong." This line finds an echo in Algernon Charles Swinburne's "Anactoria," a verse that was published in the controversial Poems and Ballads (1866): "Why wilt thou follow lesser lovers? are thine / Too weak to bear these hands and lips of mine?" (I: 57). Also written in iambic pentameter, Swinburne's address of Sappho to her female lover Anactoria uses the idea of lesbian desire as a metaphor for longings that cannot be satisfied. The emphasis in "Anactoria" on Sappho's broken heart, insatiable soul, and yearning song is also a feature of Johnson's “My Little Jean." In lines 3-5 of stanza seven Johnson writes about the friendship that "will grow cold when other ties / Enslave my heart" and concludes with the sentiment: "in my soul there lies / An unknown song." This idea that another "tie" will "enslave [her] heart" suggests that Johnson sees the limits to her

8 "My Little Jean" is reported to be Johnson's first published work, but it is not included in her Flint and Feather (1912). Although Flint and Feather is subtitled The Complete Poems, it was hastily put together by a dying Johnson and other members of her 'Friendship Group,' and many early pieces do not appear in it. StrongBoag and Gerson claim that their search of Gems of Poetry does not yield evidence of "My Little Jean" (277n2). Even so, three different versions of "My Little Jean" exist (Johnston 61; Strong-Boag/Gerson 63; Van Steen 129). The poem quoted is reproduced from Johnston's Buckskin \& Broadcloth. 
relationship with Jean and senses she will make a 'soul'-connection elsewhere.

Jean Morton's high school album also contains "The Fourth Act," and it too was written during Johnson's high school years. ${ }^{9}$ The fourth act is often the last act; Johnson uses the opening lines to heighten the drama of actions being terminated. Because she has positioned an ending at the beginning, the poem starts off by reversing meaning. The first stanza employs pathetic fallacy that functions to connect the speaker's sorrow to a mood in nature: the light is waning, the air is stifled, dead; even the pine trees are mourning, "sobbing a weird unrest / In saddened strains" (rpt. in Van Steen 149). Another significant poetic device in the last couplet of this stanza creates a crosswise arrangement, or chiasmus, in the positioning of the words "breezes" and "die / death": "Breezes that die in a stifled breath: / O happy breezes, embraced by death" (rpt. in Van Steen 149). The chiasmus inverts the sentiment to make death happy, thereby creating a departure from the standard use of language. In the next stanza too, there is a crossover in a sequence of ideas that are reinforced, then reversed. Johnson sets up a parallel when she writes about trees reaching up, a speaker being lifted up, then she creates the reversal when that person asks to be set free: "Fir trees reaching toward the sky / In giant form / Lift me up into your arms, that I / May brave the storm. / O darling, unclasp your fair, warm hand; / "Tis better I should misunderstand" (rpt. in Van Steen 149). Conflicts result from this 'crossing.' The speaker wants both to be held and then released, and to face the event yet also misunderstand. And the way Johnson's particular textual codes have changed - the 'soothing hands' (in "My Little Jean") have now become 'clasping hands' (in "The Fourth Act") - suggests another divergence, from physical comfort and adoration to grasping.

The poet offers a resolution to the dilemmas in the last stanza (the final act) of her verse. It comes in the last lines, when she establishes authority for her speaker by inserting an initial caesura. The strong punctuation after the word "Goodbye" puts a full stop to the feelings of the misunderstood lover:

${ }^{9}$ Strong-Boag and Gerson date this poem as $1876(234)$. 
Turn in pity those tender eyes

Away from me.

The burning sorrow that in them lies

Is misery.

$\mathrm{O}$, gentlest pleader my life has known,

Goodbye. The night and I are alone. (Rpt. in Van Steen 149)

Ten years later, Johnson revised "The Fourth Act," lengthened it, renamed it ("The Firs"), and published it in the journal The Week (1886).The revision contains a significant word change: “Tis better I should misunderstand" becomes the cryptic " "Tis better I should understand" (rpt. in Foster 30; my emphasis). Furthermore, another first draft of a different poem dating from this early period shows that Johnson was revising her work in order to disguise her voice and her desire. In "Misguided" (n.d.), a poem originally composed for Jean Morton, Johnson wrote, "How frail is the craft I am steering." In "Temptation," the revision of "Misguided" that was published in the Canadian magazine Saturday Night in 1889, the entire tenor of the poem is changed by the replacement of the first person "I" with the third person pronoun "he." The final version reads, "How frail is the craft he is steering" (qtd. in Waldie 69). The same-sex eroticism may have been erased from the work because Morton had begun dating Douglas Reville. ${ }^{10}$

In the next set of poems that relate Johnson's feelings for another woman, Floretta Maracle, ${ }^{11}$ the poet expresses her love by writing of concealment. The verse addressed to Maracle was first published as "Iris to Floretta" in the June 1885 issue of Gems of Poetry. While it was later renamed "To Florette Maracle," the original title, and the content of the poem, brings Johnson's work in line with that of other nineteenth-century poets who make suggestive allusions to female erotic arousal through the symbolism of flowers.

Johnson's lyric, divided into six three-line stanzas, is constructed in a highly regular pattern of iambic tetrameter. The first stanza's

${ }^{10}$ When Morton and Reville married in 1893, Johnson curiously presented her "bonny friend" with a foot high white marble statuette of a Greek slave girl (Foster 51).

11 The name Floretta is also written as Florence, Florette, and Florrie. Floretta Katherine Maracle, the youngest of six sisters, taught school in Oshweken on the Grand River Reservation until approximately 1888 when she moved to Ottawa to work with the Indian Department (Johnston 48). 
slightly distorted rhyme - "among / song / long" — is the only place where the author forces sound: "They both live side by side, among / The wooded banks of endless song / Where wild birds carol all day long" (rpt. in Van Steen 130). Elsewhere, the endings are all true rhymes: "The iris grows beneath the ledge / Of bank, all overgrown with sedge / That creeps along the river's edge" (rpt. in Van Steen 130). Throughout, Iris speaks to Floretta in a language that is the same as the late-nineteenth-century rhetoric of romantic love. Both women are described as "strong," "pure," and "true," and "They both live where they daily meet / Temptations, through their lives so sweet, / An undercurrent 'round their feet" (rpt. in Van Steen 130). The alliance between technique and theme seems especially poignant here, as enjambment at the end of the first line runs the words "meet / Temptations" together to push at the artificial and conventional edge and stride across the verse-line. The subversive contours of temptation, and the dreamlike undercurrents of desire appear more and more in the next series of love poems.

During this mid-1880s period, Johnson stopped dedicating her verse to women and no longer indicated the gender of the speaker or the beloved. It is these undedicated, gender-neutral poems that have been collected in the complete works. Sappho also expunged the addressee from the verse, making it difficult to prove that all of her poems are declarations of woman-to-woman love. In one lyric, Sappho writes about "ungovernable passions of all sorts" (qtd. in Donoghue 248), while Johnson entertains "impossible romances" and "Indefinable sweet fancies." 12 Sappho's writing recalls the pleasant things she did with her female friends - laying on soft beds, taking refuge in sanctuaries (Lardinois 18). This became a discourse belonging to a particular sapphic sensibility into which Johnson tapped. In "The Idlers" (1890), a Swinburnian-styled lyric that is written as a nine stanza verse, Johnson locates her lovers in a birchbark canoe on a slow moving river. The title is a reference to the observation that the boat has coasted landward, and the canoeists

12 "In the Shadows" was written in 1885 and first published four years later in Lighthall's Songs of the Great Dominion (1889), then collected under Johnson, Flint and Feather: The Complete Poems 72. Unless otherwise specified, all further quotations from Johnson's poems are taken from this standard work and are indicated by $\mathrm{FF}$ and the page numbers. 
have "let [their] paddles rest" (FF 60). Words that reinforce the notion of idleness, and that are all found in the first seven stanzas, include "indolent," "abandoned," and "languor." The sense of freedom that accompanies this inactivity is apparent in the qualifiers "unrepressed," "unconfined," and "unreserved." In their sanctuary, "far / From where his kisses are," the seduction begins:

Your costume, loose and light,

Leaves unconcealed your might

Of muscle, half suspected, half defined;

And falling well aside,

Your vesture opens wide,

Above your splendid sunburnt throat that pulses unconfined.

(FF 61)

At the turn of the poem (stanza six), the two canoeists' hands touch and then one person (identified as "I") kisses the "very wind that blows about your tumbled hair." Immediately after the kiss, the other's "ardour wakes" and the language shifts away from a celebration of the body to a kind of punishment:

The paddles lie disused,

The fitful breeze abused,

Has dropped to slumber, with no after-blow;

And hearts will pay the cost,

For you and I have lost

More than the homeward blowing wind that died an hour ago. (FF 62)

All is different now: nature is no longer her speaker's ally, weeping for her as it did in a previous era. In this poem, because they have "abused" the breeze, it "puffs," then "dies," then there comes a heartfelt "cost" with the threat of an "after-blow."

Poems published after Johnson began touring extensively with Smily include "Through Time and Bitter Distance" (1892), or the nostalgic "At Sunset" (1892), which contains the intoxicating line: "And some hot soul seems throbbing close to mine, / As sinks the sun within that world of wine" (FF 63). Estranged from the urges of nature she is, nonetheless, drawn back into those remembered fantasies of river and canoe, setting sun, swift water. By the time she penned the famous "The Song My Paddle Sings" (1892), she had found the appropriate metaphor for her irregular meters in the rhythm and swing of a canoe paddle. 
The work of the early 1890 s is hypnotic, particularly "Penseroso" (1892) and the intensely sexual "Wave-Won" (1892). In the latter poem, the speaker addresses her "beloved," her "dear," and begs that person to recall being afloat together in a "light and lonely shell" (FF 68). A seven-stanza verse, "Wave-Won" is written in a common six-line rhyming pattern (aabccb) called the tail rhyme or rime coué. While the tail rhyme is associated with Middle English romances (and with Chaucer), other practitioners of the verse include the poets whom Johnson no doubt read as a child, such as William Wordsworth and Alfred Lord Tennyson. But Johnson's poem strikes its own note through its irregular line lengths. While the predominant foot is trimeter (lines 1,2, and 4), it slips into the basic pentameter (line 3) and then into an even longer heptameter that actually breaks itself down into a unit of five feet followed by a run-on line of two feet. Some of the closing feet have feminine endings, and some masculine. These variations create differences in speed, stress, and nuance, all important elements for performance. The long lines intermingled with shorter ones also create tensions, or gradations of excitement. Hence, in line 3, the iambic pentameter sets up a pulsing rhythm as one lover bows down in an intimate gesture and places her "head so near my lap," then the syntax tumbles into the next verse-line with a long dash and we get a strong, highly stressed runon line that brings the stanza to a heptameter climax:

Your splendid eyes aflame

Put heaven's stars to shame,

Your god-like head so near my lap was laid-

My hand is burning where

It touched your wind-blown hair,

As sweeping to the rapids verge, I changed my paddle blade. (FF 69)

By making that lover divine, the poet is able to keep the gender secret. Her reference to "change[ing] my paddle blade" can be read as a play on this idea. In the end, both paddler and passenger surrender to their desire. The concluding stanza exults: "in delirium reeled / Our maddened hearts that kneeled / To idolize the perfect world, to taste of love at / last" (FF 69).

If the poems from the early 1890 s are about memory, the ones from the middle of the decade are about loss. In the center of "Thistledown" (1894) the lovers beach their canoe "where sands in shadows 
lie / You hold my hand a space, then speak good-bye" (FF 101). Like the earliest lyrics (and like "The Idlers" and "Wave-Won") there is a focus on hands. But unlike "My Little Jean" that predicts the subject's heart will "grow cold," these more mature pieces suggest a rekindling. Words such as "heated," "aflame," "burning," "bloom," and "stir" are more characteristic of the later verse and they bring a clear erotic element to the work. In "Moonset" (1894) Johnson writes: "lost melody stirs / The love of long ago" and adds, cryptically, "I may not all your meaning understand, / But I have touched your soul in shadow-land" (FF 42; my emphasis). The references to song and soul echo another early poem to Jean Morton that expressed the feelings of a thwarted lover. In "The Fourth Act," the speaker, who wished to "misunderstand" the other's intentions, asks to be set free. Then later in "Moonset," we see an attempt not just to comprehend herself but to understand the intentions of the other as well. Further, in "Moonset" the words "melody," "love," and "soul" create a textual dialogue with Swinburne's "On the Cliffs," a poem about the spirit of Sappho that was published in the British poet's Songs of the Spring-Tides (1880). Swinburne writes: "Since thy first lesbian word / Flamed on me, and I knew not when I knew / This was the song that struck my whole soul through" (I: 614-15). The parallel implies Swinburne's influence on Johnson.

With the exception of "Fire-Flowers" (1894), few poems of a romantic nature were published during the long period when Johnson was on tour with Smily. "Fire-Flowers" was included in the SmilyJohnson skit "There and Back" and printed in the Canadian newspaper The Globe (15 Dec. 1894). In this two-stanza verse, the poet compares love to a forest fire that scorches and scars the "sweet wild flower" (FF 122). The floral reference echoes her first poem to Floretta Maracle, when the narrator veils herself as "Iris" and writes of the powerful "undercurrent" of inwardly felt and outwardly directed desire. Notably, in the 1894 verse, Johnson discretely admits that "fellow-feeling" - a code for same-sex love - has sparked once more: "There comes some purifying sweet belief, / Some fellow-feeling beautiful, if brief. / And life revives, and blossoms once again" (FF 122).

'Fellow-feeling' possibly germinated again near the end of the nineteenth century and that may have had something to do with Johnson's broken engagement with Charles Drayton (between 
Christmas 1899 and 9 January 1900). Immediately after this, from February 1900 to April 1901, Johnson's day-to-day life is a mystery. She went to the Atlantic provinces but left few records behind and likely did not perform; she hired a new manager (Charles Wurz) and lost $\$ 500$, then suffered an acute illness (Keller 154-55). During this period, she wrote three short confessional love poems. The first unpublished piece, "Morrow Land" was composed on Holy Saturday, 1900 , and in the poem she plays on the ambiguity of "this passion week." At the beginning of the simple three-stanza verse, the distance between lovers is lamented - it is clear that they are miles apart and cannot meet soon. In the third stanza of "Morrow Land," a yearlong separation is described: "But oh, these days will be so dear / Through all the bleak and coming year, / This passion week of gold and grey, / Will haunt my life and bless my way / In Morrow Land" (qtd. in Keller 158-59). And exactly one year later, during Holy Week, 1901 , the poet resurfaces into public life, leaving the impression that her 'exile' was planned to the minute.

Keller's reading of "Heidleburgh" - the second unpublished lyric dated to the summer of 1900 - identifies the love interest in the poem as Charles Wurz. Keller's argument is very convincing: "First, Wurz came from Heidelberg, Germany ... Second, his hair was blond and his eyes were grey: the physical traits of the man in Pauline's classic fantasy of white-man-marries-Indian-maiden. Third, he arrived in Pauline's life when she felt most alone. Fourth, Pauline not only expected but was reconciled to the fact that this man would leave her" (160). It does appear that the poet was conducting a "test' because in "Heidleburgh" she writes of "storm and stress and rain" and the speaker laments being "born in vain." The "storm and stress" reference may be to the German literary movement and so serve as more evidence, perhaps, of Wurz's influence. Yet the notion that she was "born in vain" finds a perfect echo in Swinburne's "Anactoria," a poem that is also about desire mixed with pain and frustration, the bitterness of love, the agony of separation, and the longing for obliteration of the self. The lines "Yea, they shall say, earth's womb has borne in vain / New things, and never this best thing again; / Borne days and men, born fruits and wars and wine, / Seasons and song, but no song more like mine" (I: 66) come at a point after Sappho has ditched her male lover Atthis for the female Anactoria. 
The feelings of distress, and uselessness, shift by the time Johnson pens the third short confessional poem, "Song." The date of composition has been estimated both as the summer of 1900 (Keller 158 ) and as the summer of 1901 (Strong-Boag/Gerson 143). In any case, the formal twelve-line ballad is arranged in tight iambic pentameter quatrains using two sets of rhymes (abab). Since the conventions associated with the ballad are sincerity and openness (Fussell 134), it is noteworthy that this poem is the only one from the period ever published, and at that posthumously in Canadian Magazine (1913) (see Mackay). In "Song" the speaker no longer seems distraught for love, "Because you came to me, like a new day / Born of the beauty of an autumn night" (qtd. in Keller 159). This verse offers us some poetic closure too, as it harks back, again, to her late1870s "My Little Jean" about a pure love unsullied by 'manly' physical desire and the notion that in the speaker's soul there lies an "unknown song." With "Song," then, "The silence that enfolded me so long / Stirred to the sweetest music life had known / Because you came, and coming woke the song / That slumbered through the years I was alone" (qtd. in Keller 159). Throughout the poem the influence of Swinburne's "Anactoria" - a verse dedicated to Sappho, his "supreme head of song" - can be heard in references to seasons, to rebirth, and, of course, to music and "the song."

When Swinburne writes of Sappho he often connects her physicality (in particular, her skin coloration and her beauty) to homoerotic passion, as in these lines from "On the Cliffs" (1880): "The small dark body's lesbian loveliness / That held the fire eternal" (I: 620). The idea of dark skin and comeliness is celebrated by Johnson's "The Idlers" (1890), "Harvest Time" (1894), "Lady Lorgnette" (1903), and "The King's Consort" (1912). These poems, particularly "Lady Lorgnette," contradict Johnson's ambivalent feelings about her own "washed out Mohawk skin" (qtd. in StrongBoag/Gerson 212) and link the issue of race with some of the devices she uses in her poetry to express sapphic desire.

"Lady Lorgnette" is a long poem divided into two sections, each of which is loosely shaped (through rhyme and sometimes meter) into Shakespearean sonnets. Following the convention of the sonnet form, the first part of each section poses a problem that finds resolution in the couplet of the final two lines, also referred to as "the turn" (Fussell 121-22). The two dilemmas in "Lady Lorgnette" 
concern performing gender in front of an audience and connecting this performance to race, and to sexuality. The focus of the first section is an audience member - Lady Lorgnette of the title. The speaker, an actor identified as "a mimic king," is separated from Lady Lorgnette by the edge of the stage, yet close enough to smell her perfume and to notice the "Madame's" pale-colored skin, jewels, and clothing. The speaker confesses:

I may act till the world grows wild and tense,

But never a flush on your features pale...

I am only an actor, Madame, to you,

A mimic king 'mid his mimic lords,

For you are the belle of the smartest set,

Lady Lorgnette. (FF 85)

The final couplet pivots on the conjunction "For," which grants the spectator in her box her class ("smartest set") and her beauty ("belle"), and identifies the narrator gazing down at "the Lady" as a mere 'mimicry.' The speaker's act, which has come under close inspection via the Lady's 'lorgnette,' has failed in some way because the Madame's "pale" skin did not "flush."

In the next section, the speaker's gaze targets a different audience member, Little Babette, who stands with the "mob" in the "pit":

Little Babette, with your eyes of jet,

Your midnight hair and your piquant chin,

Your lips whose odours of violet

Drive men to madness and saints to sin, -

I see you over the footlights' glare

Down in the pit 'mid the common mob, -

Your throat is burning, and brown, and bare,

You lean, and listen, and pulse, and throb. (FF 85)

The code word "violets" and the language of physical desire "burning," "pulse," "throb" - identifies this dark-skinned spectator as the desired woman. Yet because she "lean[s]" and "listen[s]" intently, Little Babette is a desiring woman too, and hence her role is dual. The mimic king goes on to address this audience member as "dear" and to comment about her reaction to the performance:

The viols are dreaming between us two,

And my gilded crown is no make-believe,

I am more than an actor, dear, to you,

For you called me your king but yester eve, 
And your heart is my golden coronet,

Little Babette. (FF 86)

The words "sin" and "crown" also appear in the letter Johnson sent to her friend Kate Simpson-Hayes during the year the poet was supposed to be engaged to a man (see rpt. in Strong-Boag/Gerson 96). These words, along with her 'manly' heart, hands, songs, canoes, and flowers, comprise part of Pauline Johnson's personal sapphic code that hints at an eroticized exchange.

Elsewhere, Johnson writes "there are two of me" ("Fate of the Red Man" n.p.) in order to reinforce her double-voiced, doublegarbed persona. She has also revealed that "one of the secrets of good writing of any kind is the power of being someone else" (qtd. in Mackay 274). In "Lady Lorgnette," a dual role (of desired, and desiring, woman) is found not only in the dark-skinned audience member, but also in the speaker of the poem, the "mimic king." By emphasizing in this poem the 'manly' nature of her persona, it can be seen that this 'othered' position (as mimic "king") allows Johnson some degree of freedom when she is placed in a public role. In terms of sapphic wampum, as performer (in this case) of a male poetic persona, she plays with her appearance as a "king" to connect with female members of the audience. Hence, "Lady Lorgnette," a depiction of the cross-dressed actor gazing down at her female audience members - and watching as the brown-skinned Babette lustily stares back - identifies that Johnson is conscious of the complexities of the performing gaze performing gender. Similarly, earlier on in her career she wanted to appear in a different guise feminine "Indian" dress - in order to be an "interesting topic with ladies" (see letter qtd. in Strong-Boag/Gerson 110).

As we have seen, the assumption of male clothes on and off the stage was part of the social and cultural practice of lesbianism of the nineteenth and early twentieth centuries. Johnson seems to register aspects of this sexual richness in her various costumes, in her performances, in her verse, and in her relations with women. In "Lady Lorgnette," as well as in earlier poems, Johnson speaks as a woman to women: her eroticism is both subjectively and objectively woman-centered. Too often critics have tried to restrict her eros to the realm of Platonic friendships, whereas I have argued for pervasive allusions to a discourse and a life that is sexualized. It seems clear that Pauline Johnson made a personal and subjective commitment 
to lesbianism. Reading her poems in this way can enhance our sense of Johnson as part of a tradition of favored codes, poetic devices, and sexual dualities that have, through the ages, recorded the nature of sapphic desire.

\section{Works Cited}

Alcott, Louisa May. "Happy Women.” New York Ledger 24 (11 Apr. 1868): n.p.

Bennett, Paula. "Critical Clitoridectomy: Female Sexual Imagery and Feminist Psycho-analytical Theory.” Signs 18 (1993): 235-59.

Dickason, Olive Patricia. Canada's First Nations: A History of

Founding Peoples from Earliest Times. Norman: University of

Oklahoma Press, 1992.

Donoghue, Emma. Passions Between Women: British Lesbian Culture 1668-1801. New York: Harper, 1995.

Duncan, Sara Jeannette [Garth Grafton]. "Woman's World." Globe 14 Oct. 1886: n.p.

Everard, Myriam. "Lesbian History: A History of Change and Disparity." Journal of Homosexuality 12 (1986): 123-37.

Faderman, Lillian. Surpassing the Love of Men: Romantic Friendship and Love Between Women from the Renaissance to the Present. New York: Morrow, 1981.

Foster, Annie. Mohawk Princess: Being Some Account of the Life of Tekahion-wake (E. Pauline Johnson) . Vancouver: Lions' Gate, 1931.

Frost, Robert. "The Secret Sits" in Poetry and Prose. Ed. Edward

Connery Lathem and Lawrance Thompson. New York: Holt, 1972.

Fussell, Paul. Poetic Meter and Poetic Form. Rev. Ed. New York: Random, 1979.

Gray, Charlotte. Flint \& Feather: The Life and Times of E. Pauline Johnson, Tekahionwake. Toronto: Harper, 2002.

Gregory, Gill. The Life and Work of Adelaide Procter: Poetry, Feminism and Fathers. Aldershot: Ashgate, 1998.

Johnson, E. Pauline [Tekahionwake]. "Fate of the Red Man." Ottawa Free Press 21 June 1894. n.p. 
- Flint and Feather: The Complete Poems. Eighth Ed. Toronto: Musson, 1922.

-The Shagganappi. Toronto: Briggs, 1913.

- The White Wampum. London: Lane, 1895.

Johnston, Sheila M.F. Buckskin \& Broadcloth: A Celebration of E. Pauline Johnson - Tekahionwake 1861-1913. Toronto: Natural Heritage, 1997.

Keller, Betty. Pauline: A Biography of Pauline Johnson. Vancouver: Douglas \& McIntyre, 1981.

Lardinois, André. "Lesbian Sappho and Sappho of Lesbos." From Sappho to De Sade: Moments in the History of Sexuality. Ed. Jan Bremmer. London: Routledge, 1989: 15-35.

Lesbian History Group. Not a Passing Phase: Reclaiming Lesbians in History, 1840-1985. London: Women's Press, 1989.

Lister, Anne. I Know My Own Heart: The Diaries of Anne Lister 1791-1840. Ed. Helena Whitbread. London: Virago, 1988.

Mackay, Isabel Ecclestone. "Pauline Johnson: A Reminiscence." Canadian Magazine 41 (July 1913): 273-78.

Martin, Sandra. "The Persistence of Pauline." Globe \& Mail [Toronto] 19 Aug. 2000: D3.

McRaye, J. Walter. Pauline Johnson and Her Friends. Toronto: Ryerson, 1947.

Morgan, Fidelis. The Well-Known Trouble Maker: A Life of Charlotte Charke. London: Faber, 1988.

Rooksby, Rikky. A. C. Swinburne: A Poet's Life. Aldershot: Scolar, 1997.

Strong-Boag, Veronica and Carole Gerson. Paddling Her Own Canoe: The Times and Texts of E. Pauline Johnson. Toronto: University of Toronto Press, 2000.

Stutfield, Hugh E. M. "Tommyrotics.” Blackwood's Magazine 157 (1895): 833-45.

Swinburne, Algernon Charles. Collected Poetical Works. 2 vols. London: Heinemann, 1924.

Terry, Jennifer. An American Obsession: Science, Medicine, and Homosexuality in Modern Society. Chicago: University of Chicago Press, 1999.

Van Steen, Marcus. Pauline Johnson: Her Life and Work. Toronto: Musson, 1965. 
62 / Revie

Vicinus, Martha. “'They Wonder to Which Sex I Belong': The Historical Roots of the Modern Lesbian Identity." The Lesbian and Gay Studies Reader . Ed. Henry Abelove, et al. New York: Routledge, 1993. 432-52.

Waldie, Jean H. "The Iroquois Poetess, Pauline Johnson." Ontario History 40 (1948): 65-75.

"Were Her Wishes Observed?" The Native Voice: Special Pauline Johnson Centenary Edition 15.7 (July 1961): 13-15. 